Article

\title{
Putative Genes of Pathogenesis-Related Proteins and Coronatine-Insensitive Protein 1 in Ribes spp.
}

\author{
Ana Dovilè Juškytė *(D), Ingrida Mažeikienè $(D)$ and Vidmantas Stanys $(D$
}

check for

updates

Citation: Juškytè, A.D.; Mažeikienè,

I.; Stanys, V. Putative Genes of

Pathogenesis-Related Proteins and

Coronatine-Insensitive Protein 1 in

Ribes spp. Plants 2022, 11, 355.

https://doi.org/10.3390/

plants11030355

Academic Editors: Giedrè Samuolienè, Neringa Rasiukeviciute,

Lina Šernaitè, Darius Kviklys and

Kappei Kobayashi

Received: 27 October 2021

Accepted: 26 January 2022

Published: 28 January 2022

Publisher's Note: MDPI stays neutral with regard to jurisdictional claims in published maps and institutional affiliations.

Copyright: (C) 2022 by the authors. Licensee MDPI, Basel, Switzerland. This article is an open access article distributed under the terms and conditions of the Creative Commons Attribution (CC BY) license (https:// creativecommons.org/licenses/by/ $4.0 /)$.
Lithuanian Research Centre for Agriculture and Forestry, Institute of Horticulture, Kaunas str. 30, Babtai, 54333 Kaunas, Lithuania; ingrida.mazeikiene@lammc.lt (I.M.); vidmantas.stanys@lammc.lt (V.S.)

* Correspondence: ana.dovile.juskyte@lammc.lt; Tel.: +370-3755-5253

Abstract: In response to pathogen attacks, plants activate a complex of defense mechanisms including an accumulation of the endogenous signaling compounds salicylic acid and jasmonic acid. The activity of pathogenesis-related genes (PRs) and coronatine-insensitive 1 (COI1) in defense-response pathways are established in plants. The aim of this study was to identify homologs of the PRs and COI1 in blackcurrants. Primers with degenerate nucleotides were designed based on the most conservative parts of PR1 and COI1 genes from other plants and applied for amplification of specific fragments of $P R$ s and COI1 in Ribes spp. Seven heterogeneous sequences of $P R$ with a diversity of $66.0-98.3 \%$ at nucleic acid level were found. The phylogenetic analysis revealed the dependence of $R$. nigrum $P R$ homologs on the PR1 and PR6 families. Four heterogeneous sequences of R. nigrum COI1 with an identity of $95.9-98.8 \%$ at nucleic acid level were isolated. Specific primers for newly detected genes' homologs were designed in this study and could be useful for evaluating the defense response to pathogen attacks in blackcurrants.

Keywords: blackcurrant; defense response; gene homolog; pathogenesis-related genes; coronatineinsensitive 1

\section{Introduction}

Blackcurrant (Ribes nigrum L.) is an economically important berry, widely grown in the temperate climate zones of Europe, Asia, New Zealand, Australia, and North America. Fruits and other vegetative parts of Ribes spp. have a rich nutritional composition, so they are widely used in food, pharmacology, and the cosmetics industry [1]. Blackcurrant plantations worldwide are adversely affected by various pests, pathogens and diseases. The breeding of resistant cultivars is a top priority; however, the application of new biotechnological methods in Ribes breeding is limited by a lack of genetic knowledge and unsequenced genome [2]. To this day, only a few genes and molecular markers specific to pathogen and pest resistance have been established in some Ribes species [3-7]. This is why genetic mechanisms of resistance in Ribes genus are unknown, and the metabolic pathway involved in defense response after pest or pathogen infection is limited [8].

Plants have developed a complex defense system against biological agents of various scales, from microscopic viruses to phytophagous insects. The components of this immune system rely on their ability to recognize pathogen molecules, carry out signal transduction and respond defensively through pathways involving many genes and their products. The relevance of defense-related hormones such as salicylic acid (SA), jasmonic acid (JA) and ethylene (ET) as primary signals in the regulation of signal transduction cascades in plant defense has been widely investigated [9]. Once pathogens overcome mechanical barriers to infection, plant receptors initiate signaling pathways, stimulating the defense-response genes' expression [10]. Inducible defenses include a rapid oxidative burst, accumulation of elevated levels of endogenous signaling compounds, induction of defense-related genes and production of antimicrobial enzymes [11]. 
Pathogenesis-related proteins (PRs) are plant species that specific proteins induce by biotic stress, and they play an important role in plant defense against pathogenic fungi, virus, bacteria, and insects. In addition to their protective function, they are also involved in plant hormone regulation and cell development [12]. Proteins encoded by PR genes have been classified into 17 families according to sequence homology, isoelectric points, reaction with specific antisera and mRNA probes [13]. Most $P R$ genes are induced through the action of SA and JA signaling compounds and possess antimicrobial activities in vitro through hydrolytic activities on cell walls, contact toxicity and perhaps an involvement in defense signaling. PRs are associated with systemic acquired resistance (SAR) and can act locally on pathogens in the cell or through enzymatic activity [14,15].

Plant pathogens deploy an array of virulence factors, such as phytotoxin coronatine (COR), to suppress host defense and promote pathogenicity [16]. COR can mimic bioactive JA compounds in plants, thus targeting JA receptors to coronatine insensitive 1 (COI1) gene expression and inhibiting the SA-signaling pathway of defense [17]. The JA-responsive defense-related gene COI1, which has been identified as insensitive to COR A. thaliana mutants, is required for resistance to insect herbivory and resistance to pathogens [18]. In addition to its protective function against pests, COI1 is also involved in other plant physiological processes: growth inhibition, reproduction and regeneration [19].

The aim of this study was to identify homologs of the PRs and COI1 genes in Ribes spp. emphasizing the $R$. nigrum genome.

\section{Results}

\subsection{Development and Application of PR and COI1 Primer Pairs}

One of the goals in our study was to design oligonucleotide primers suitable for Ribes spp. that are distinct from other agricultures in taxonomy. The most distinctive sequences from rarer woody garden plants and other dicotyledons were chosen for alignments and primers design (Figure 1).

$P R$ genes have been extensively studied in plants, and families from PR1 to PR17 are recognized. The genome of Ribes spp. has been insufficiently investigated, and this has led to difficulties in biotechnological approaches. The PRPd primer pair (Table 1) with degenerate nucleotides was designed according to data on multiple nucleic acid alignment of PR1 genes in 18 plant species (Figure S1). The sites with the highest homology were located from 66 to 88 and from 435 to 458 nucleic acids in the C. annuum (the NCBI database accession number is AF053343.2) sequence of the whole PR1 gene (Figure 1A). The sites' similarity of sequences selected for forward and reverse primers design were $77.7 \%$ and $84.1 \%$, respectively. The COId primer pair with degenerate nucleotides (Table 1 ) was designed comparing COI1 gene sequences from 22 plant species according to the NCBI database (Figure S2). The primer pair for detection of COI1 in Ribes spp. was designed from the most conservative sites of the gene, from 1383 to 1406 and from 1712 to 1735 nucleic acids., according to the $A$. thaliana sequence (NM_129552.4) (Figure 1B). The sequence homology at the primer sites was $89.7 \%$ for forward direction and $81.7 \%$ for reverse direction among 22 plant species.

Table 1. Selected primer pairs with degenerate nucleotides for $P R$ and $C O I$ detection.

\begin{tabular}{|c|c|c|c|c|c|}
\hline Primer & Orientation & Oligonucleotide Sequences $5^{\prime}$ to $3^{\prime}$ & $\begin{array}{c}\text { Temperature, } \\
{ }^{\circ} \mathrm{C}\end{array}$ & Length, bp & $\begin{array}{l}\text { Position in the } \\
\text { Gene, bp }\end{array}$ \\
\hline PRPd & $\begin{array}{l}\text { Forward } \\
\text { Reverse }\end{array}$ & $\begin{array}{l}\text { GCMCARRAYWCHCCMCAAGAYT } \\
\text { TTGCCNSGDGGATCRTAAYTGCA }\end{array}$ & 63 & 392 & $66-458$ \\
\hline COId & $\begin{array}{l}\text { Forward } \\
\text { Reverse }\end{array}$ & $\begin{array}{l}\text { AGYCMAAAYGTRAGATGGATGCT } \\
\text { TTCTYKGWCCWGCHAGDGARTAR }\end{array}$ & 61 & 352 & 1383-1735 \\
\hline
\end{tabular}

These newly designed primer pairs with degenerate nucleotides (Table 1 ) were applied for detection of PR and COI1 homologs in various Ribes species by PCR (Figure 2). The 
entire lengths of PR1 and COI1 in the plants were approximately 500 and 1780 nucleotides, respectively (according to the NCBI database, Table S1). The primer pair PRPd was suitable to amplify $392 \mathrm{bp}$ length product from the middle of the $P R$ gene by PCR. The primer pair COId flanked part of the COI1 gene at the $3^{\prime}$ end, from 1383 to $1735 \mathrm{bp}$.

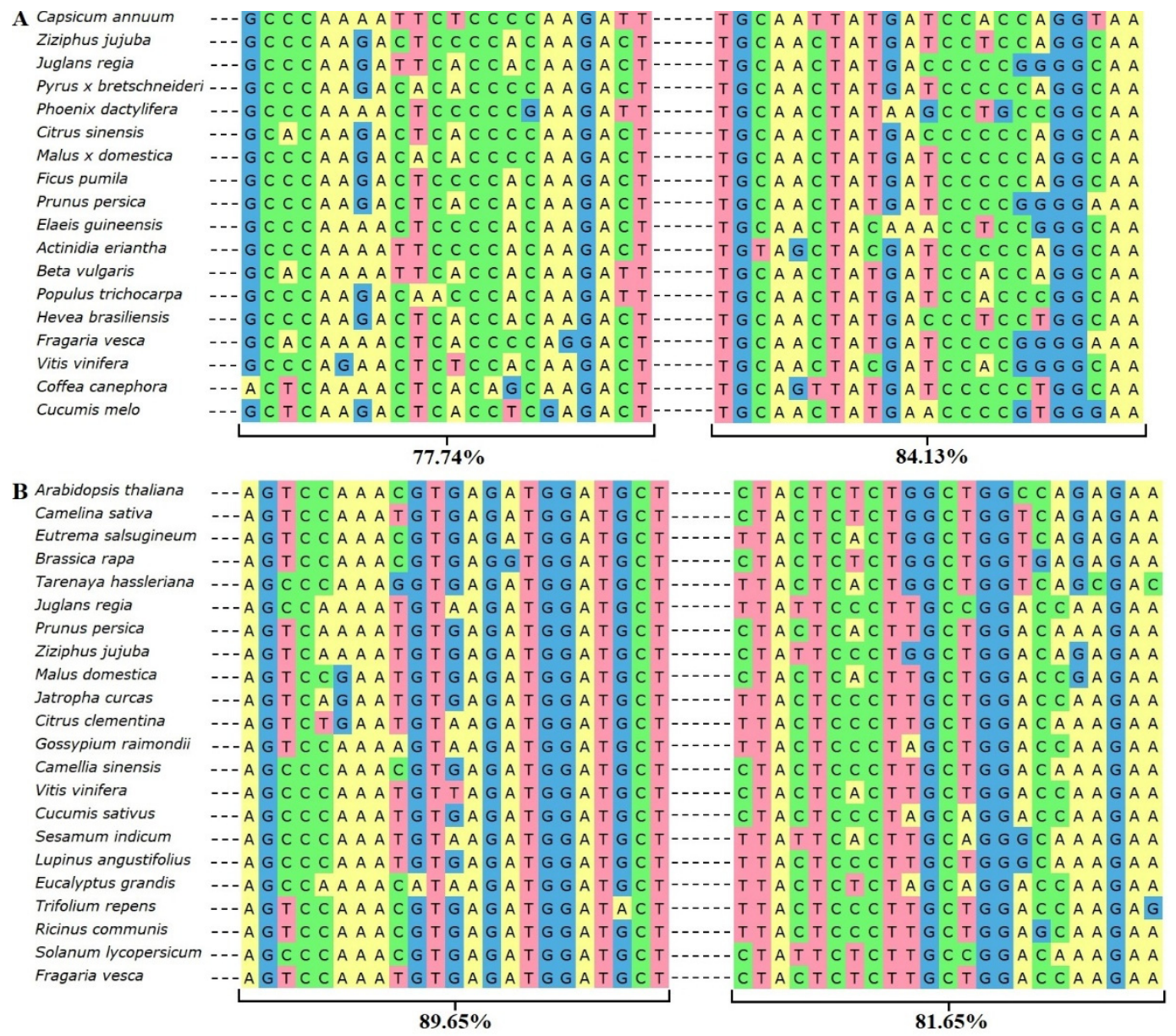

Figure 1. Alignments of the most conservative sites of PR1 (A) and COI1 (B) genes in various plants. Accession numbers of presented plants in Figure 1 are available in Table S1.

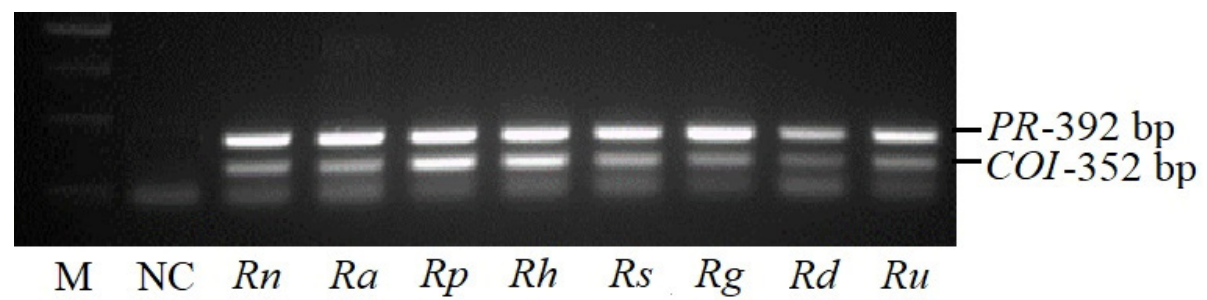

Figure 2. Amplified PCR fragments obtained with primer pairs PRPd and COId in Ribes species. M-size standard 250, 500, 750, 1000 bp; NC—negative control; $R n-R$. nigrum; Ra-R. americanum; $R p-R$. pauciflorum; $R h-R$. hudsonianum; $R s-R$. sanguineum; $R g-R$. glandulosum; $R d-R$. dikusha; $R u-R . u v a-c r i s p a$.

The PCR application of the primers PRPd and COId was performed in eight Ribes species: R. nigrum cv. Didikai, R. americanum, R. pauciflorum, R. hudsonianum, R. sanguineum, R. glandulosum, R. dikusha and R. uva-crispa. Specific size fragments for the $P R(392 \mathrm{bp})$ and COI1 (352 bp) were amplified in tested species (Figure 2). For further genetic study, specific products of COI1 and PR genes from R. nigrum (Figure 2, column 3) were excised from purified agarose gel, and DNA samples of 20 plasmids after transformation were sequenced. 


\subsection{Multiple Sequence and Phylogenetic Analysis of PR Homologs of R. nigrum}

Seven heterogeneous sequences of $P R$ were identified in the blackcurrant mRNA: PRP_1, PRP_2, PRP_3, PRP_4, PRP_7, PRP_8 and PRP_9 (accession numbers in the NCBI database are OK625407-OK625413) (Table S5). Partial sequences of PR identified in this study were in position 28-152 amino acids, compared with the whole gene of $V$. vinifera (XP_002273416.1) (Figure 3). The substitutions and deletions among the sequences are shown in Figure 3. All PR isolates of $R$. nigrum had mutations at the amino acid level. The percent identity among the nucleotide sequences obtained in $R$. nigrum ranged from 66.0 to $98.3 \%$, and from 63.2 to $98.5 \%$ at amino acid level (Table S3). A multiple sequence alignment with $V$. vinifera showed that the $R$. nigrum $P R$ isolates had $54.7 \%$ identical and $13.3 \%$ conservative amino acids (Figure 3 ). According to deletions of amino acids and substitutions of semi-conservative $(10.9 \%)$ or non-conservative $(21.1 \%)$ amino acids, two groups of $R$. nigrum isolates were visible: PRP_1, PRP_3 and PRP_9, and PRP_2, PRP_4, PRP_7 and PRP_8. The CAP superfamily domain (Cysteine-Rich Secretory Proteins, Antigen 5, and Pathogenesis-Related 1 Proteins), which is underlined in Figure 3, shows the dependence of newly detected blackcurrant isolates on the PR gene family.

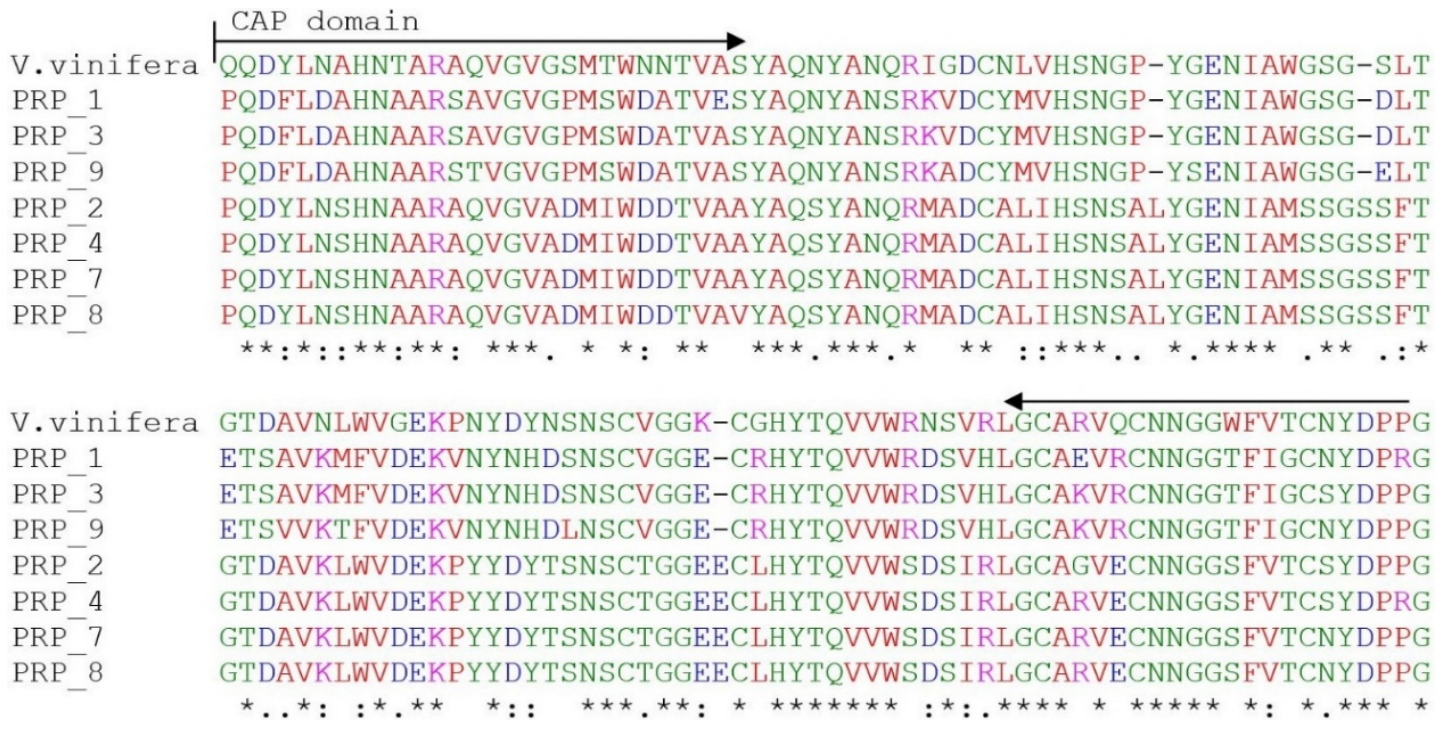

Figure 3. A multiple alignment of seven $R$. nigrum isolates and part of $P R 1$ gene of $V$. vinifera (whole PR1 is 160 amino acids, according to the accession number XP_002273416.1). The underlined sequence marks the CAP domain. The comparative sequence is the amino acids for residues 28-152 of the protein. Identity of amino acids: *-identical, :- conservative, .- semi-conservative, space-nonconservative.

Phylogenetic analysis of seven $P R$ homologs of $R$. nigrum was conducted in a general context of 22 plants (Figure 4). The $P R$ homologs were divided into two distinct branches, as PR1 and PR6 families at $100.0 \%$ bootstrap. A separate branch consisted of three $R$. nigrum isolates-PRP_1, PRP_3 and PRP_9_-that are likely to be PR1 homologs. Another four isolates-PRP_8, PRP_7, PRP_2 and PRP_4-were grouped in another branch of phylogenetic tree and showed a clear dependence on the family PR6. Isolates PRP_7 and PRP_8 of putative gene PR6 were genetically distinguished at $65.0 \%$ bootstrap. Newly identified $P R$ isolates in blackcurrants appeared as members of the PR1 and PR6 families, although they also showed the uniqueness of the Ribes genus from other plants at bootstrap $100 \%$ in both branches of the phylogenetic dendrogram (Figure 4). 


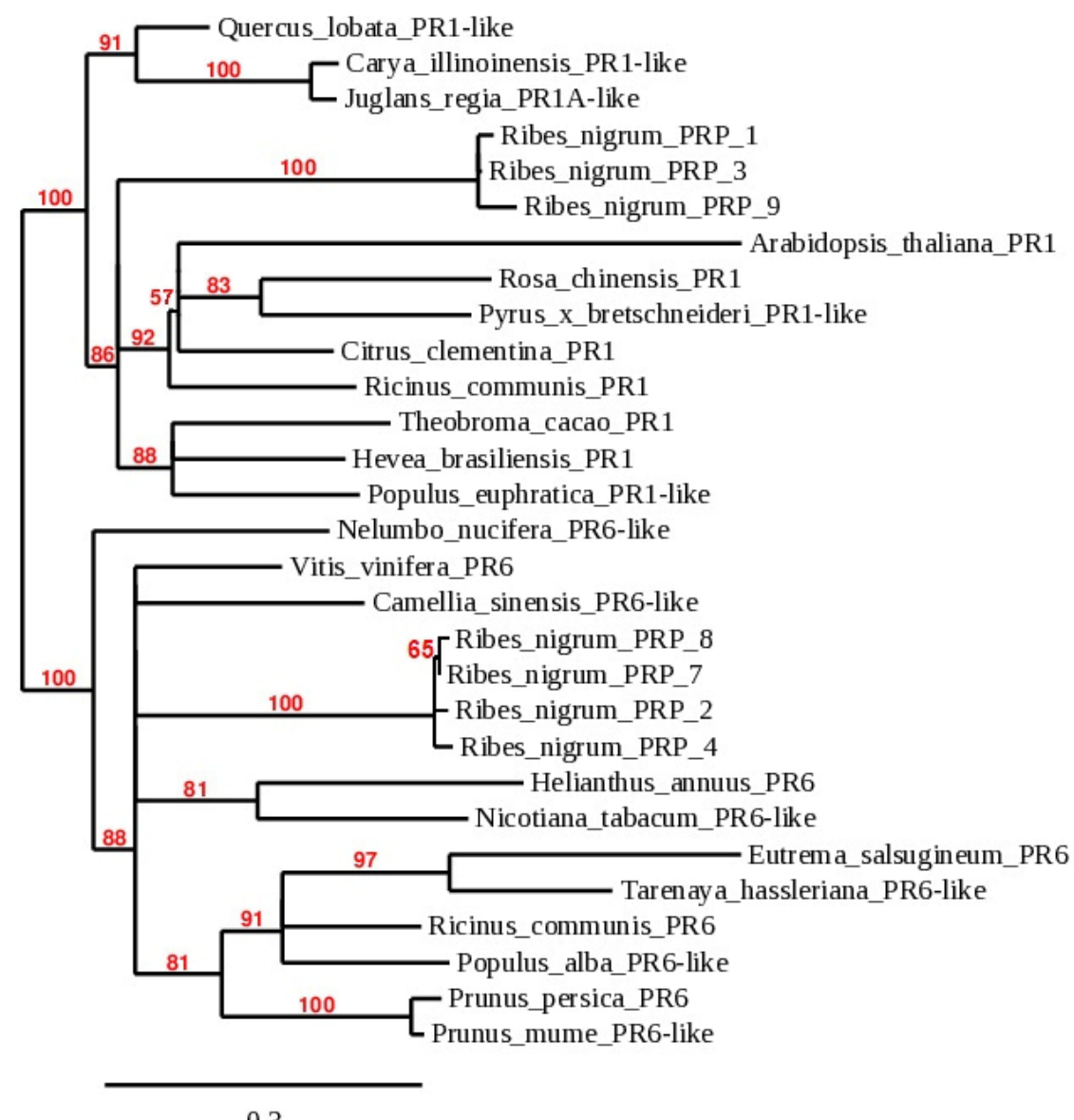

Figure 4. Phylogenetic dendrogram of $P R$ genes constructed according to nucleotide sequences of 22 plant species. Accession numbers of newly obtained $P R$ sequences of $R$. nigrum in our research are OK625407-OK625413 (Table S5); accession numbers of other plants in Figure 4 are available in Table S2.

\subsection{Multiple Sequence and Phylogenetic Analysis of COI Homologs of R. nigrum}

The COI1 gene consisted of 603 amino acids in S. lycopersicum (NP_001234464.1) plants. Part of the COI1 homologs sequenced in Ribes spp. consisted of 114 amino acids at the $3^{\prime}$ end of the COI1 gene. Four heterogeneous isolates-COI_4.2.7, COI_5, COI_8 and COI_9were submitted to the NCBI database with the accession numbers OK625547-OK625550, respectively (Table S5). Multiple alignments among sequences showed relatively high homology with part of the COI1 gene in S. lycopersicum (Figure 5); $73.7 \%$ of identical and $11.4 \%$ of conservative amino acids were detected. Two conservative leucine-rich repeat (LRR) regions in the R. nigrum sequences were determined. Between sequences, semiconservative $(8.8 \%)$ and non-conservative $(6.1 \%)$ amino acid substitutions were detected, and Glycine $(\mathrm{G})$ deletion in R. nigrum isolates were found. 


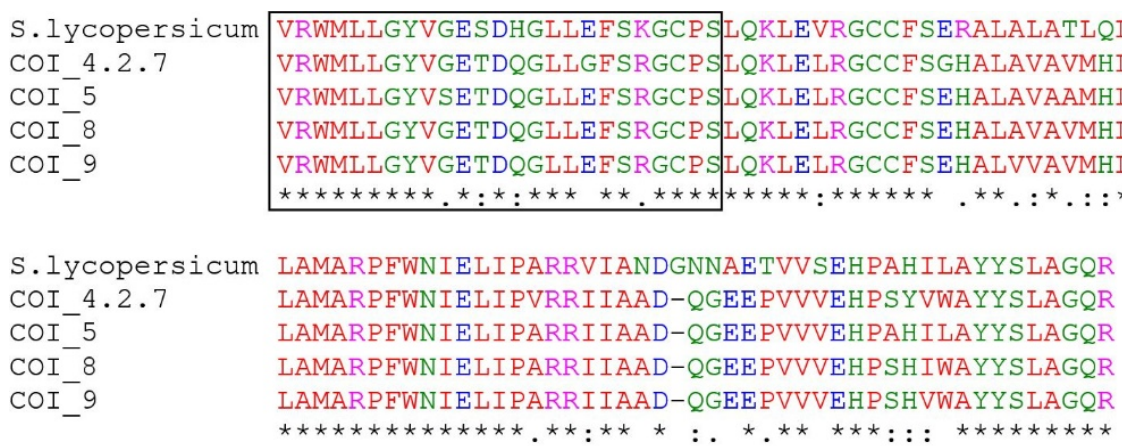

Figure 5. A multiple alignment of four R. nigrum isolates and part of COI1 gene of S. lycopersicum (whole COI1 is 603 amino acids, according to the accession number NP_001234464.1). Sequence part in boxes indicate two leucine-rich repeat (LRR) regions. The comparative sequence is the amino acids for residues 471-585 of the protein. Identity of amino acids: *-identical, :-conservative, .- -semi-conservative, space-non-conservative.

In the phylogenetic tree, 22 nucleotide sequences from various plants (Figure 6), including four identified isolates in the R. nigrum genome, showed dependence on the COI1 family. All COI1 homologs presented in the dendrogram were divided into two branches at $99.0 \%$ bootstrap, and they revealed the arrangement of $R$. nigrum COI homologs COI_5, COI_4.2.7,COI_8 and COI_9 in the separate branch in the second clade of the dendrogram. R. nigrum isolates were heterogeneous, and identity among them ranged from 95.9 to $98.8 \%$ (Table S4) in amino acid level.

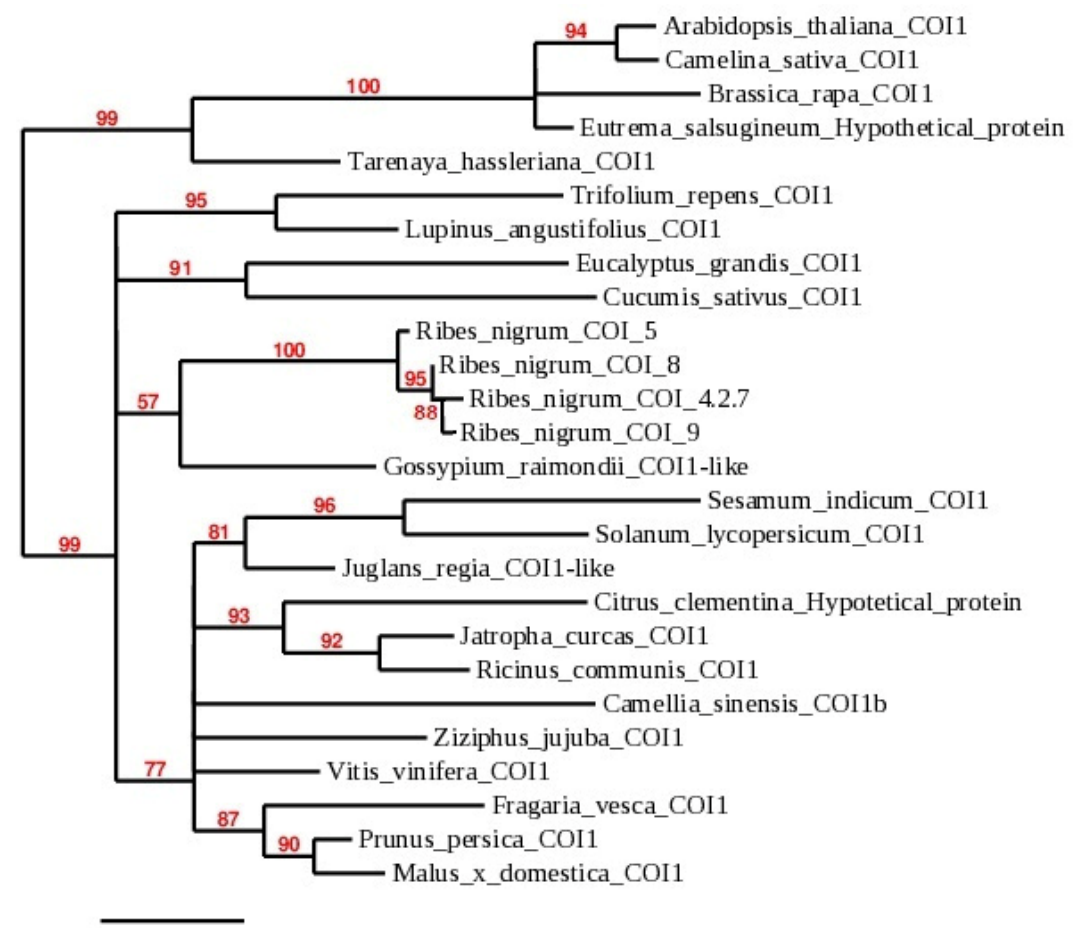

0.1

Figure 6. Phylogenetic dendrogram of COI1 genes constructed from nucleotide sequences of 22 plant species. Accession numbers of newly obtained COI1 sequences in R. nigrum in our research are OK625547-OK625550 (Table S5); accession numbers of other plants in Figure 6 are available in Table S2.

According to the distribution of the R. nigrum PR1, PR6 and COI1 homologs in the phylogenetic trees (Figures 4 and 6) and data of multiple sequence alignments (Figures 3 and 5), 
six pairs of specific primer pairs were generated (Table 2). Primers were approved for DNA synthesis initiation by PCR in two R. nigrum cultivars: Aldoniai and Ben Tirran (Figure 7). The primer pair PRP_2847 allowed us to amplify a 155 bp-specific fragment of putative PR6 in R. nigrum cDNA. According to the sequences of isolates (PRP_1, PRP_3 and PRP_9), the primer pair PRP_913 was generated, which flanked the fragment of $191 \mathrm{bp}$ in length of the putative PR1 sequence. The primer pair Ribes_PRP was suitable for PRs detection in Ribes spp. plants, and a specific fragment of $396 \mathrm{bp}$ in length was amplified (Figure 7).

Table 2. Specific $P R$ and COI primer pairs for Ribes spp.

\begin{tabular}{|c|c|c|c|c|}
\hline Primer & Orientation & Oligonucleotide Sequences $5^{\prime}$ to $3^{\prime}$ & Temperature, ${ }^{\circ} \mathrm{C}$ & Length, bp \\
\hline PRP_2847 & $\begin{array}{l}\text { Forward } \\
\text { Reverse }\end{array}$ & $\begin{array}{l}\text { AGCACAAGTTGGTGTTGCAG } \\
\text { TAAAAGAACTACCGCTGCTCATT }\end{array}$ & 60 & 155 \\
\hline PRP_913 & $\begin{array}{l}\text { Forward } \\
\text { Reverse }\end{array}$ & $\begin{array}{l}\text { CTTGGGGAAGTGGTGAACTAAC } \\
\text { ATGGAGGAACATTTATCGGATG }\end{array}$ & 59 & 191 \\
\hline Ribes_PRP & $\begin{array}{l}\text { Forward } \\
\text { Reverse }\end{array}$ & $\begin{array}{c}\text { CCCAGGACTCACCCCAAGATT } \\
\text { TGCCTGGGGGATCGTAATTG }\end{array}$ & 63 & 396 \\
\hline COI_5 & $\begin{array}{l}\text { Forward } \\
\text { Reverse }\end{array}$ & $\begin{array}{c}\text { AGCCTTCAGAAACTGGAATTGA } \\
\text { GCCAGGGAGTAATATGCTAGTATATGT }\end{array}$ & 60 & 260 \\
\hline COI_247 & $\begin{array}{l}\text { Forward } \\
\text { Reverse }\end{array}$ & $\begin{array}{c}\text { AGTCCAAACGTGAGATGGATGCTT } \\
\text { AGCCCAAACGTAAGATGGATGCT }\end{array}$ & 63 & 327 \\
\hline Ribes_COI & $\begin{array}{l}\text { Forward } \\
\text { Reverse }\end{array}$ & $\begin{array}{c}\text { CACCTGACTGCTCTGAGGTACTTA } \\
\text { AACGACTACAGGTTCCTCTCCTT }\end{array}$ & 60 & 156 \\
\hline
\end{tabular}

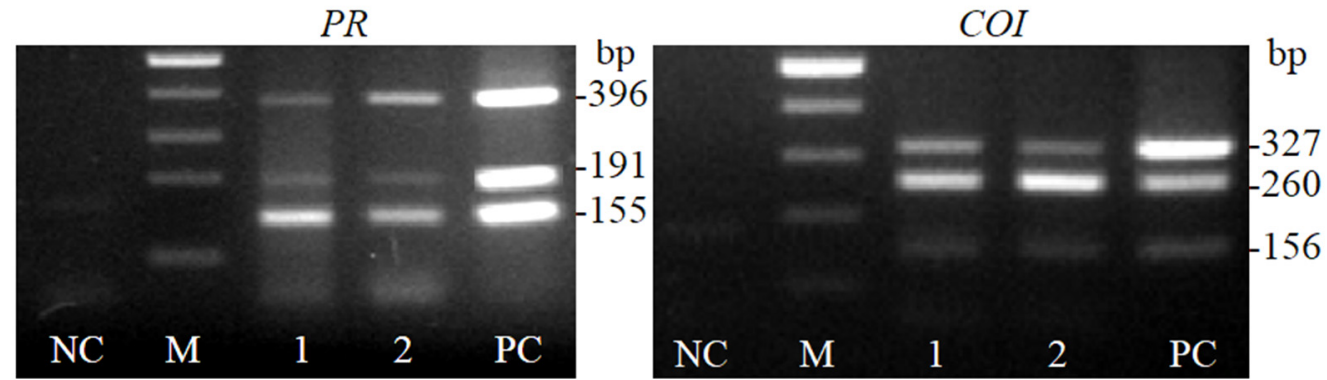

Figure 7. PCR products amplified with newly designed primer pairs specific to R. nigrum PRs, PR1, PR6 and COI1 genes. NC—negative control; M—size standard 100, 200, 300, 400, 500 bp; 1—cDNA of cv. Aldoniai; 2-cDNA of cv. Ben Tirran; PC—positive control.

Although all newly detected COI homologs in R. nigrum belong to the COI1 family, the nucleic and amino acid differences between them led to the creation of different primers. $R$. nigrum isolates COI_5 and COI_247 differ in their phylogeny; thus, an individual primer pair for each of them was designed. The specific fragment of $260 \mathrm{bp}$ in length was obtained with the primer pair COI_5 (Table 2), while a fragment of 327 bp in length was obtained using the primer pair COI_247. Ribes_COI was a general primer pair for identification of COI1 in blackcurrants (Figure 7).

\section{Discussion}

Abundant studies on $P R$ and COI1 homologs in many economically important crop cultures and modeling plants have been carried out $[15,20,21]$. The Ribes genome, belonging to the taxon Saxifragales, needs further study, and the PRs and COI1 genes have also not been identified until now. The actions of these genes in different defense pathways in plants has been approved [14-16]. Based on the conservatism and ancient phylogenetic origin of these genes, their functions are likely to be similar in Ribes spp. to those of other plants. Phylogenetic analysis in this study provided evidence that $R$. nigrum contains PR1, PR6 and COI1 homologs with heterogeneity at nucleic acid and amino acid levels (Figures 3 and 5). 
R. nigrum PR homologs from families PR1 (isolates PRP_1, PRP_3 and PRP_9) and PR6 (isolates PRP_2, PRP_4,PRP_7 and PRP_8) were found, which confirms the presence of the CAP domain in protein sequences and the data of phylogenetic analysis (Figures 3 and 4). Proteins of families of PR accumulate after the interaction of pathogens and may act as antifungal agents in other plants [22]. It is known that PRs' activity is induced by biotic stress, and that they play an important role in plant defense against pathogenic fungi, viruses, bacteria and insects [23]. After reviewing aspects of this $P R$ study, it was observed that the expression of $P R 1$ genes has been extensively studied in response to different types of insects and pathogen attacks in various plant species: fungus in rice [24], fungus, viruses and insects in wheat [25], bacteria in apple [26], etc. PR1 is the most abundant family, and the expression of genes is usable as a molecular marker to indicate plant defense response [27]. The action of the PR1 family members during viral infection is also known [21]. According to the literature, members of the PR6 family are proteinase inhibitors related to defense response against insects, herbivores, microorganisms and nematodes [28]. It has been suggested that PR6 can be important in plant response to abiotic stresses such as heavy metals, salt, water deficit or mechanical wounding [20,29-31]. It was determined that the biotrophic pathogen activates the SA-signaling pathway in plants that stimulates the accumulation of $P R 1, P R 2$ and $P R 5$ products that systematically lead to SAR and can act locally [32]. In contrast, insufficient studies were conducted on PR6. The identification and characterization of the PR6 family have been demonstrated in Gramineae [33], Leguminosae [34] and Solanaceae families [35], and expression analysis was performed in P. ginseng in response to signaling molecules to abiotic stresses [36].

All the COI1 homologs identified in blackcurrants in this study belong to the COI1 family; however, the Ribes genus has an individual phylogenetic way in species evolution (Figure 6). COI1 is a key regulator involved in the wound or JA-signaling pathway required for plant-defense response [19]. Similar studies were performed, providing data that transcription of COI1 differs in response to nematode infection in white clover [37], fungus infection in wheat [38] and virus infection in tobacco [39] and rice [40].

Newly designed primer pairs with degenerate oligonucleotides for Ribes genus and specific primers for $R$. nigrum were validated and are suitable for the identification of $P R s$, PR1, PR6 and COI1 homologs by PCR (Tables 1 and 2, Figure 7). However, in this study, we have not evaluated the expression of these genes, so we can only assume the function and relevance of these genes for Ribes plants. To elucidate the role of these protective genes in blackcurrants, it is necessary to carry out further experiments on genes' expression. For this purpose, stress factors must be modified and applied to plants in an in vitro system. Sequencing, comparative and in silico analysis revealed and evaluated the origin, diversity and mutations of partial PRs and COI1 genes in R. nigrum plants. Now, we can develop a strategy for genetic engineering of the $R$. nigrum in vitro through overexpression of $P R$ and COI proteins' coding genes. The development and validation of specific primers suitable for the identification of the putative PR1, PR6 and COI1 genes of blackcurrants expand the possibilities for explaining the significance of these genes in Ribes spp. plants during biotic and abiotic stress.

\section{Materials and Methods}

\subsection{Plant Material, RNA Extraction and cDNA Synthesis}

Total RNA from homogenized leaves of $R$. nigrum cv. Didikai, R. americanum, $R$. pauciflorum, R. hudsonianum, R. sanguineum, R. glandulosum, R. dikusha, R. uva-crispa and two blackcurrant cultivars, Ben Tirran and Aldoniai, was extracted using GeneJET Plant RNA Purification Mini Kit (Thermo Scientific, Vilnius, Lithuania). Isolated RNA was used to synthesize cDNA using Maxima H Minus First Strand cDNA Synthesis Kit (Thermo Scientific, Vilnius, Lithuania). The concentration of cDNA was measured with an Implen $\mathrm{GmbH}$ spectrophotometer and stored at $-20{ }^{\circ} \mathrm{C}$ until the reaction. 


\subsection{Primers Design and Polymerase Chain Reaction (PCR)}

Degenerate oligonucleotide primer pairs for detection of $P R$ and COI by PCR were designed using the Primer3plus program [41]. Primers were selected from the conservative sites of the genes by comparing sequences of other plants from the NCBI database. Alignments of the 18 PR1 and 22 COI1 nucleotide sequences were performed (Table S1, Figures S1 and S2).

Fragments of putative genes PR1 and COI1 in selected plant material were amplified using the PCR method. PCR was performed in a $20.0 \mu \mathrm{L}$ reaction volume containing $11.1 \mu \mathrm{L}$ $\mathrm{H}_{2} \mathrm{O}, 2.5 \mu \mathrm{L} \mathrm{Taq}+\mathrm{KCl}$ buffer, $2.0 \mu \mathrm{L} 2 \mathrm{mM}$ dNTP mix, $2.0 \mu \mathrm{L} \mathrm{MgCl} 2,2.0 \mu \mathrm{L}$ cDNA, $0.2 \mu \mathrm{L}$ Taq polymerase (Thermo Scientific, Vilnius, Lithuania) and $0.1 \mu \mathrm{L}$ of each forward and reverse primer. The DNA was amplified using the following thermocycling steps: $95{ }^{\circ} \mathrm{C}$ for $3 \mathrm{~min}$; 35 cycles of denaturing at $94^{\circ} \mathrm{C}$ for $30 \mathrm{~s}$; annealing (temperatures are given in Tables 1 and 2) for $30 \mathrm{~s}$; extending at $72{ }^{\circ} \mathrm{C}$ for $40 \mathrm{~s}$; followed by a final step at $72{ }^{\circ} \mathrm{C}$ for 5 min and hold at $4{ }^{\circ} \mathrm{C}$. The PCR products were resolved by electrophoresis through a $1.3 \%$ agarose gel and visualized by ethidium bromide staining and UV illumination.

\subsection{Fragment Purification, Cloning and Sequencing}

The amplified R. nigrum cv. Didikai cDNA fragments were excised from agarose gel and purified using the GeneJET Gel Extraction Kit (Thermo Scientific, Vilnius, Lithuania) according to the manufacturer's protocol. Fragments were ligated into the pJET 1.2 blunt vector using the CloneJET ${ }^{\mathrm{TM}}$ PCR Cloning Kit (Thermo Scientific, Vilnius, Lithuania). Bacteria Escherichia coli JM107 were transformed with the TransformAid Bacterial Transformation Kit (Thermo Scientific, Vilnius, Lithuania). A total of 20 plasmids with cDNA inserts of $P R$ and COI homologs were prepared for sequencing using the Big Dye Terminator v 3.1 Cycle Sequencing Kit and performed on a 3130 Genetic Analyzer Gene Analyzer (Applied Biosystem, Waltham, MA, USA). The sequenced 7 PR and 4 COI nucleotide sequences from $R$. nigrum were submitted to the NCBI database, and the accession numbers OK625407-OK625413 and OK625547-OK625550, respectively, were assigned (Table S5).

\subsection{Statistical Analysis}

The PR1 and COI1 sites, from which primers with degenerate nucleotides were generated, were visualized using the UGENE program (Kalign alignment) [42]. The multiple amino acid sequences' alignments of PRs and COI1 were performed with ClustalW (MUSCLE 3.8) [43] according to the S. lycopersicum COI1 sequence (accession number NP_001234464.1 in the NCBI database) and the $V$. vinifera PR1 sequence (accession number XP_002273416.1 in the NCBI database). The percent identity matrixes at amino acid and nucleic acid levels among the genes identified in $R$. nigrum were created using the Clustal 2.1 program. The phylogenetic dendrograms among the different plants (Table S2) and the obtained sequences in $R$. nigrum (Table S5) were constructed using the maximum likelihood method implemented in the PhyML program; a bootstrap analysis with 100 replications was performed [44].

Supplementary Materials: https:/ / www.mdpi.com/article/10.3390/plants11030355/s1, Table S1: Plant species and their accession numbers from NCBI database, used in degenerate COI and PR primers; Figure S1: Multiple alignment of PR1; Table S2: Plant species and their accession numbers from NCBI database, used for COI and $P R$ phylogenetic analysis; Figure S2: Multiple alignment of COI1; Table S3: Percent identity matrix of $P R$ isolates at nucleic acid and amino acid levels identified in R. nigrum cv. Didikai; Table S4: Percent identity matrix of COI isolates at nucleic acid and amino acid levels identified in $R$. nigrum cv. Didikai; Table S5: The sequenced 7 PR and 4 COI isolates and their accession numbers identified in blackcurrant mRNA.

Author Contributions: Conceptualization, I.M. and A.D.J.; methodology, A.D.J. and I.M.; software, A.D.J. and I.M.; formal analysis, V.S.; investigation, A.D.J. and I.M.; resources, V.S.; data curation, A.D.J.; writing—original draft preparation, A.D.J.; writing—review and editing, I.M. and V.S.; vi- 
sualization, A.D.J.; supervision, I.M. All authors have read and agreed to the published version of the manuscript.

Funding: This research received no external funding.

Institutional Review Board Statement: Not applicable.

Informed Consent Statement: Not applicable.

Data Availability Statement: The study did not report any data.

Conflicts of Interest: The authors declare no conflict of interest.

\section{References}

1. Brennan, R.; Jorgensen, L.; Hackett, C.; Woodhead, M.; Gordon, S.; Russell, J. The development of a genetic linkage map of blackcurrant (Ribes nigrum L.) and the identification of regions associated with key fruit quality and agronomic traits. Euphytica 2008, 161, 19-34. [CrossRef]

2. Brennan, R.; Graham, J. Improving fruit quality in Rubus and Ribes through breeding. Funct. Plant Sci. Biotechnol. 2009, 3, 22-29.

3. Anderson, M.M. Resistance to gall mite (Phytoptus ribis Nal.) in the Eucoreosma section of Ribes. Euphytica 1971, $20,422-426$. [CrossRef]

4. Knight, R.L.; Keep, E.; Briggs, J.B.; Parker, J.H. Transference of resistance to black currant gall mite Cecidophyopsis ribis, from goosebery to black currant. Ann. Appl. Biol. 1974, 76, 123-130. [CrossRef]

5. Keep, E. Cytoplasmic male sterility, resistance to gall mite and mildew, and season of leafing out in black currants. Euphytica 1986, 35, 843-855. [CrossRef]

6. $\quad$ Brennan, R.; Jorgensen, L.; Gordon, S.; Loades, K.; Hackett, C.; Russell, J. The development of a PCR-based marker linked to resistance to the blackcurrant gall mite (Cecidophyopsis ribis Acari: Eriophyidae). Theor. Appl. Genet. 2009, 118, 205-211. [CrossRef]

7. Mazeikiene, I.; Bendokas, V.; Stanys, V.; Siksnianas, T. Molecular markers linked to resistance to gall mite in blackcurrant. Plant Breed. 2012, 131, 762-766. [CrossRef]

8. Mazeikiene, I.; Juskyte, A.D.; Stanys, V. Application of marker-assisted selection for resistance to gall mite and Blackcurrant reversion virus in Ribes genus. Zembirbyste 2019, 106, 359-366. [CrossRef]

9. Verhage, A.; Wees, S.C.M.; Pieterse, C.M.J. Plant immunity: It's the hormones talking, but what do they say? Plant Physiol. 2010, 154, 536-540. [CrossRef]

10. Andersen, E.J.; Ali, S.; Byamukama, E.; Yen, Y.; Nepal, M.P. Disease resistance mechanisms in plants. Genes 2018, 9, 339. [CrossRef]

11. Glazebrook, J.; Rogers, E.E.; Ausubel, F.M. Use of Arabidopsis for genetic dissection of plant defense responses. Annu. Rev. Genet. 1997, 31, 547-569. [CrossRef]

12. Upadhyay, P.; Rai, A.; Kumar, R.; Singh, M.; Sinha, B. Differential Expression of Pathogenesis Related Protein Genes in Tomato during Inoculation with A. Solani. J. Plant Pathol. Microbiol. 2014, 5, 217. [CrossRef]

13. Van Loon, L.C.; Rep, M.; Pieterse, C.M.J. Significance of Inducible Defense-related Proteins in Infected Plants. Annu. Rev. Phytopathol. 2006, 44, 135-162. [CrossRef]

14. Ebrahim, S.; Usha, K.; Singh, B. Pathogenesis Related (PR) Proteins in Plant Defense Mechanism. In Science against Microbial Pathogens: Communicating Current Research and Technological Advances; Méndez-Vilas, A., Ed.; Formatex Research Center: Badajoz, Spain, 2011; pp. 1043-1054.

15. Ali, S.; Ganai, B.A.; Kamili, A.; Bhat, A.A.; Mir, Z.A.; Bhat, J.A.; Tyagi, A.; Islam, S.T.; Mushtaq, M.; Yadav, P.; et al. Pathogenesisrelated proteins and peptides as promising tools for engineering plants with multiple stress tolerance. Microbiol. Res. 2018, 212-213, 29-37. [CrossRef]

16. Geng, X.; Jin, L.; Shimada, M.; Kim, G.; Mackey, D. The phytotoxin coronatine is a multifunctional component of the virulence armament of Pseudomonas syringae. Planta 2014, 240, 1149-1165. [CrossRef]

17. Chini, A.; Boter, M.; Solano, R. Plant oxylipins: COI1/JAZs/MYC2 as the core jasmonic acid-signalling module. FEBS J. 2009, 276, 4682-4692. [CrossRef]

18. Katsir, L.; Schilmiller, A.L.; Staswick, P.E.; He, S.Y.; Howe, G.A. COI1 is a critical component of a receptor for jasmonate and the bacterial virulence factor coronatine. Proc. Natl. Acad. Sci. USA 2008, 105, 7100-7105. [CrossRef]

19. Devoto, A.; Ellis, C.; Magusin, A.; Chang, H.S.; Chilcott, C.; Zhu, T.; Turner, J.G. Expression profiling reveals COI1 to be a key regulator of genes involved in wound- and methyl jasmonate-induced secondary metabolism, defence, and hormone interactions. Plant Mol. Biol. 2005, 58, 497-513. [CrossRef]

20. Dombrowski, J.E. Salt stress activation of wound-related genes in tomato plants. Plant Physiol. 2003, 132, 2098-2107. [CrossRef]

21. Boccardo, N.A.; Segretin, M.E.; Hernandez, I.; Mirkin, F.G.; Chacón, O.; Lopez, Y.; Borrás-Hidalgo, O.; Bravo-Almonacid, F.F. Expression of pathogenesis-related proteins in transplastomic tobacco plants confers resistance to filamentous pathogens under field trials. Sci. Rep. 2019, 9, 2791. [CrossRef]

22. Gibbs, G.M.; Roelants, K.; O'Bryan, M.K. The CAP Superfamily: Cysteine-Rich Secretory Proteins, Antigen 5, and PathogenesisRelated 1 Proteins-Roles in Reproduction, Cancer, and Immune Defense. Endocr. Rev. 2008, 29, 865-897. [CrossRef]

23. Van Loon, L.C. Pathogenesis-related proteins. Plant Mol. Biol. 1985, 4, 111-116. [CrossRef] 
24. Mitsuhara, I.; Iwai, T.; Seo, S.; Yanagawa, Y.; Kawahigasi, H.; Hirose, S.; Ohkawa, Y.; Ohashi, Y. Characteristic expression of twelve rice PR1 family genes in response to pathogen infection, wounding, and defense-related signal compounds. Mol. Genet. Genom. 2008, 279, 415-427. [CrossRef]

25. Wu, S.; Wang, H.; Yang, Z.; Kong, L. Expression Comparisons of Pathogenesis-Related (PR) Genes in Wheat in Response to Infection/Infestation by Fusarium, Yellow dwarf virus (YDV) Aphid-Transmitted and Hessian Fly. J. Integr. Agric. 2014, 13, $926-936$. [CrossRef]

26. Bonasera, J.M.; Kim, J.F.; Beer, S.V. PR genes of apple: Identification and expression in response to elicitors and inoculation with Erwinia amylovora. BMC Plant Biol. 2006, 6, 23. [CrossRef]

27. Sudisha, J.; Sharathchandra, R.G.; Amruthesh, K.N.; Kumar, A.; Shetty, H.S. Pathogenesis Related Proteins in Plant Defense Response. In Plant Defence: Biological Control; Merillon, J.M., Ramawat, K.G., Eds.; Springer: Dordrecht, The Netherlands, 2011; Volume 12, pp. 379-403.

28. VanLoon, L.C.; VanStrien, E.A. The families of pathogenesis-related proteins, their activities, and comparative analysis of PR-1 type proteins. Physiol. Mol. Plant Pathol. 1999, 55, 85-97. [CrossRef]

29. Sánchez-Hernández, C.; Martínez-Gallardo, N.; Guerrero-Rangel, A.; Valdés-Rodríguez, S.; Délano-Frier, J. Trypsin and $\alpha$-amylase inhibitors are differentially induced in leaves of amaranth (Amaranthus hypochondriacus) in response to biotic and abiotic stress. Physiol. Plant 2004, 122, 254-264. [CrossRef]

30. Joshi, R.S.; Tanpure, R.S.; Singh, R.K.; Gupta, V.S.; Giri, A.P. Resistance through inhibition: Ectopic expression of serine protease inhibitor offers stress tolerance via delayed senescence in yeast cell. Biochem. Biophys. Res. Commun. 2014, 452, 361-368. [CrossRef]

31. Guerra, F.P.; Reyes, L.; Vergara-Jaque, A.; Campos-Hernández, C.; Gutiérrez, A.; Pérez-Díaz, J.; Pérez-Díaz, R.; Blaudez, D.; Ruíz-Lara, S. Populus deltoides Kunitz trypsin inhibitor 3 confers metal tolerance and binds copper, revealing a new defensive role against heavy metal stress. Environ. Exp. Bot. 2015, 115, 28-37. [CrossRef]

32. Ali, S.; Mir, Z.A.; Tyagi, A.; Bhat, J.A.; Chandrashekar, N.; Papolu, P.K.; Rawat, S.; Grover, A. Identification and comparative analysis of Brassica juncea pathogenesis-related genes in response to hormonal, biotic and abiotic stresses. Acta Physiol. Plant. 2017, 39, 268. [CrossRef]

33. Rakwal, R.; Agrawal, G.K.; Jwa, N.S. Characterization of a rice (Oryza sativa L.) Bowman-Birk proteinase inhibitor: Tightly light regulated induction in response to cut, jasmonic acid, ethylene and protein phosphatase 2A inhibitors. Gene 2001, 263, 189-198. [CrossRef]

34. Jamal, F.; Pandey, P.K.; Singh, D.; Ahmed, W. A Kunitz-type serine protease inhibitor from Butea monosperma seed and its influence on developmental physiology of Helicoverpa armigera. Process Biochem. 2014, 50, 311-316. [CrossRef]

35. Zhang, H.Y.; Xie, X.Z.; Xu, Y.Z.; Wu, N.H. Isolation and functional assesment of tomato proteinase inhibitor II gene. Plant Physiol. Biochem. 2004, 42, 437-444. [CrossRef]

36. Myagmarjav, D.; Sukweenadhi, J.; Kim, Y.J.; Jang, M.G.; Rahimi, S.; Silva, J.; Choi, J.Y.; Mohanan, P.; Kwon, W.S.; Kim, C.G.; et al Molecular Characterization and Expression Analysis of Pathogenesis related Protein 6 from Panax ginseng. Russ. J. Genet. 2017, 53, 1211-1220. [CrossRef]

37. Islam, A.; Mercer, C.F.; Leung, S.; Dijkwel, P.P.; McManus, M.T. Transcription of Biotic Stress Associated Genes in White Clover (Trifolium repens L.) Differs in Response to Cyst and Root-Knot Nematode Infection. PLoS ONE 2015, 10, e0137981. [CrossRef]

38. Liu, X.; Wang, J.; Fan, B.; Shang, Y.; Sun, Y.; Dang, C.; Xie, C.; Wang, Z.; Peng, Y. A COI1 gene in wheat contributes to the early defence response against wheat powdery mildew. J. Phytopathol. 2017, 166, 116-122. [CrossRef]

39. Liu, Y.; Schiff, M.; Dinesh-Kumar, S.P. Involvement of MEK1, MAPKK, NTF6 MAPK, WRKY/MYB transcription factors, COI1 and CTR1 in N-mediated resistance to tobacco mosaic virus. Plant J. 2004, 38, 800-809. [CrossRef]

40. Yang, Z.; Huang, Y.; Yang, J.; Yao, S.; Zhao, K.; Wang, D.; Qin, Q.; Bian, Z.; Li, Y.; Lan, Y.; et al. Jasmonate Signaling Enhances RNA Silencing and Antiviral Defense in Rice. Cell Host Microbe 2020, 28, 89-103. [CrossRef]

41. Untergasser, A.; Nijveen, H.; Rao, X.; Bisseling, T.; Geurts, R.; Leunissen, J.A.M. Primer3Plus, an enhanced web interface to Primer3. Nucleic Acids Res. 2007, 35, W71-W74. [CrossRef]

42. Okonechnikov, K.; Golosova, O.; Fursov, M. Unipro UGENE: A unified bioinformatics toolkit. Bioinformatics 2012, $28,1166-1167$. [CrossRef]

43. Madeira, F.; Park, Y.M.; Lee, J.; Buso, N.; Gur, T.; Madhusoodanan, N.; Basutkar, P.; Tivey, A.R.N.; Potter, S.C.; Finn, R.D.; et al. The EMBL-EBI search and sequence analysis tools APIs in 2019. Nucleic Acids Res. 2019, 47, W636-W641. [CrossRef]

44. Guindon, S.; Dufayard, J.F.; Lefort, V.; Anisimova, M.; Hordijk, W.; Gascuel, O. New Algorithms and Methods to Estimate Maximum-Likelihood Phylogenies: Assessing the Performance of PhyML 3.0. Syst. Biol. 2010, 59, 307-321. [CrossRef] 